\title{
Curricular and Co-curricular Leadership Learning for Engineering Students
}

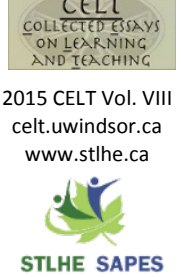

\author{
Doug Reeve ${ }^{1}$, Greg Evans ${ }^{1}$, Annie Simpson, Robin Sacks ${ }^{1}$, \\ Estelle Oliva-Fisher, Cindy Rottmann, and Patricia Sheridan ${ }^{1}$ \\ The Institute for Leadership Education in Engineering, \\ ${ }^{1}$ Also Department of Chemical Engineering and Applied Chemistry \\ Faculty of Applied Science and Engineering, University of Toronto
}

In recent years engineering educators have been encouraged to blend technical and professional learning in their curricular and co-curricular programing (Engineers Canada, 2009; National Academy of Engineering [NAE], 2004). Our paper describes a multifaceted leadership learning program developed to achieve this goal by infusing reflective, experiential learning into an otherwise technically oriented discipline. The program was designed by a collaborative team of educators and researchers with backgrounds in engineering, education, psychology, and industry and offers a range of learning experiences using diverse pedagogical strategies. The content covers four realms of leadership corresponding to four levels of analysis: self, team, organization, and society. Learning experiences include elective academic courses, co-curricular workshop programs, guest lectures in core courses, seminars, department based leadership groups, and panel discussions. In this paper, we describe the program goals, curricular and co-curricular initiatives and early research findings in order to scaffold an emerging discussion about engineering leadership education in Canada. Informal feedback from students who have participated in our program provide us with preliminary evidence that students are learning, that they value the learning opportunities afforded by our program and that our initiative is enabling significant personal growth.

\section{Introduction}

Engineers are uniquely positioned to create Cinnovative solutions to many local and global challenges (Downey et al., 2006; Engineers Canada, 2009; Katehi, 2005; Khattak, 2011; Reeve, 2010; Vest, 2005), yet few North American faculties of engineering provide students with the leadership learning opportunities required to do this work. Fortunately, recent calls for change by the National
Academy of Engineering and Engineers Canada (Engineers Canada, 2009; NAE, 2004) have led a small, but growing number of engineering educators-mostly in the United States-to infuse leadership learning opportunities into engineering education (Bayless, 2013; Cox, Osman, \& Adams, 2010; Croft, Winkelman, Boisvert, \& Patten, 2013; Evans, Reeve, \& Simpson, 2010; Graham, Crawley, \& Mendelsohn, 2009; Ha, 2013; Hsiao, 2013b; Kerns, Miller, \& Kerns, 2005; Khattak, 2011; Osagiede, Farmer Cox, \& Ahn, 2013; Pitts, 
Klosterman, \& McGonagle, 2013; Polito \& Martinich, 2008; Schuhmann, 2010; Simpson, Evans, \& Reeve, 2012). The three most prominent foci of these programs are entrepreneurship and innovation (Hsiao, 2013a; Soundarajan, Ramnath, \& Weide, 2013), personal and professional growth (Colcleugh \& Reeve, 2013; McCuen, 1999; Reeve, Simpson, \& Evans, 2010; Simpson, Evans, \& Reeve, 2010), and global citizenship (Athreya et al., 2010; Ellis \& Petersen, 2011; McMartin, 2013). The first two typically involve skill building and industry partnerships while the third concentrates on international mobility and service learning projects in the global south. The initiative we discuss in this paper-The Institute for Leadership Education in Engineering at the University of Toronto (ILead) addresses all three areas but focuses primarily on personal and professional growth. In this paper, we describe ILead's program goals, curricular and cocurricular initiatives and early research findings in order to scaffold an emerging discussion about engineering leadership education in Canada.

\section{A Multidisciplinary Approach to Program Development}

In 2002, when we began to develop leadership programming at the University of Toronto's Faculty of Applied Science and Engineering, leadership capability was acquired implicitly, if at all by engineering students. Over time the "Leaders of Tomorrow" program gained popularity among the student body and incrementally expanded to meet the growing need. In 2006, the University of Toronto Provost awarded $\$ 1$ million in funding over five years to create leadership programming across the engineering faculty that: “...strengthens the experience of engineering students by providing coherent, structured and intentional learning opportunities to enhance their leadership development." In 2009-2010, a decanal task force assessed progress in leadership education in the faculty. This institutional review led to the establishment of the Institute for Leadership Education in Engineering (ILead) dedicated to helping engineers lead change to build a better world. The institute was the first of its kind in the Canadian engineering landscape offering curricular, cocurricular and extra-curricular leadership education and empowering engineering students to succeed as leaders in their profession and beyond.

At the core of our institute is a multidisciplinary team of engineers, education specialists, and social scientists dedicated to bringing leadership learning opportunities to engineering students. This collaboration is rooted in a shared passion for student development, leadership learning, innovative teaching methods, and a commitment to creating positive impact in the world. Design and implementation of this program brought together a diverse team with a wide range of complementary professional experiences including leadership in academic and corporate settings. See Figure 1 for an illustration of the multidisciplinary framework that shaped our program development process up to and including the 2013-2014 academic year.

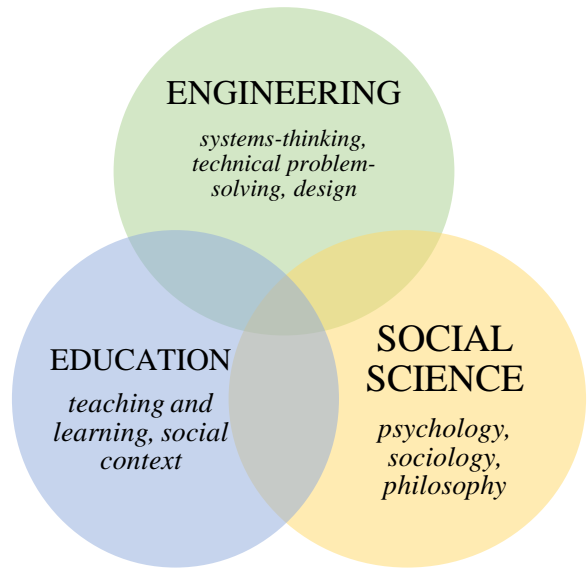

Figure 1

\section{Multidisciplinary approach to program development}

Each of the disciplines identified in this framework-engineering, social science and education-allowed us to foreground and develop a different aspect of our program. For example, the engineering perspective brought a focus on systems 
thinking and efficiency that helped us scale up instruction to enable leadership education in large classrooms. The social science perspective allowed us to examine the conceptual and disciplinary underpinnings of the emerging field of engineering leadership, and the educational perspective helped us implement these ideas in ways that were accessible, instructive and engaging to students. Beyond these three disciplinary perspectives, our team's experience in post-secondary academic administration and industry-based professional leadership allowed us to connect our program objectives to the academic and professional contexts in which engineers study and work. Finally, team members' expertise in counseling, psychology, experiential learning, design, and artsbased pedagogy contributed to a focus on personal growth that helped shape the program.

\section{Program Goals}

The overall goal of ILead programing was to create a range of complementary educational initiatives to enhance the accessibility and effectiveness of leadership learning within engineering so that students would be better positioned to lead positive change in teams, organizations, and society. Three bodies of literature have informed our work: leadership identity development theory (Komives, Lucas, \& McMahon, 1998; Kouzes \& Posner, 1987), organizational learning theory (Scharmer, 2008, Senge, 1990, Colcleugh, 2013), and experiential learning theory (Kolb, 1981, 1984). The first of these theories foregrounds the iterative, intrapersonal nature of skill building and identity development; the second reminds us that leadership learning is always contextually mediated; and the third informs our curriculum development process, encouraging us to blend concrete experiences, reflection, conceptualization, analysis and application into our coursework and co-curricular initiatives. Leadership learning is not simply about internalizing received knowledge. Our curriculum is collaboratively designed by members of the team with an educational background to include a range of experiential activities, active skill development, reflection, analysis and iterative project design. We aim to make these experiences as accessible as possible to a wide range of student learners by engaging them mentally, emotionally and kinesthetically in their learning. For example, at a workshop on facilitation skills students would be introduced to the topic, discuss the role of a facilitator, and brainstorm some responses to common interpersonal challenges that occur in groups. They may then observe a scenario or engage with a case study. Next, students practice a new skillset in the context of a simulation or group discussion and are provided with feedback on their facilitation skills. Finally, they are guided to reflect on their learning and experience as a way of enhancing the prospects that their new knowledge will be transferable to future situations. Underlying our attraction to these three theoretical perspectives is our view that:

\section{Leadership is a process that begins with self and inspires and empowers others, teams and organizations to effect positive change.}

Our strategic planning team expanded this statement into five core beliefs about leadership:

1. Leadership starts with the self: Self-awareness is a necessary foundation for effective leadership. Students must be aware of their strengths, their communication style, their personal values and work to develop greater congruence between values and actions.

2. Leadership is a relational process, not just a position: Leadership happens in the context of teams, groups, and organizations; it is a relational process. People work together to achieve a common goal. Therefore, leaders need to learn how to engage with people.

3. Everyone has the potential to be a leader: We recognize and value many different leadership styles and work to empower the natural abilities of each student. 
4. Leadership is a shared responsibility: Leadership is not the responsibility of one individual. We all have a responsibility to offer our best and to engage in the work of leadership.

5. Leadership empowers engineers: Engineers are involved in generating solutions to the world's most pressing problems (e.g. climate change, clean energy, clean water, and sustainable development). Leadership skills complement engineers' technical education and better position them to create positive change.

These core beliefs, in turn, shaped the institution's actionable mission statement:

To develop curricular, co-curricular, and extra-curricular programming for leadership education for undergraduate and graduate students in engineering; to conduct research on the pedagogy of leadership education in engineering; to conduct research on leadership practice in engineeringintensive enterprises; and to reach out to others to develop a community of practice dedicated to advancing engineering leadership.

In order to facilitate the implementation of this mission statement, the strategic planning team identified four leadership domains corresponding to four levels of analysis: self-leadership, leading teams, leading organizations and leading society. The leadership instruction framework includes the underlying beliefs and overarching goals related to each domain (See Table 1).

After the strategic planning team identified these domains, beliefs, and goals, course instructors and student service professionals translated them into specific learning objectives and pedagogical strategies most suitable for their students.

\section{Table 1}

\section{Leadership Instruction Framework}

\begin{tabular}{lll}
$\begin{array}{ll}\text { Leadership } \\
\text { Domains }\end{array}$ & \multicolumn{1}{c}{ Beliefs } & \multicolumn{1}{c}{ Overarching Goals } \\
\hline Society & $\begin{array}{l}\text { Grand challenges demand } \\
\text { leadership from great engineers }\end{array}$ & $\begin{array}{l}\text { Be an agent of change; leverage your engineering } \\
\text { expertise to create positive impact. }\end{array}$ \\
Organization & $\begin{array}{l}\text { Leadership is a process, not just } \\
\text { a position }\end{array}$ & $\begin{array}{l}\text { Optimize your value to an organization by reading } \\
\text { and shaping its currents and culture; focus your } \\
\text { talents and passions, and those of others to } \\
\text { contribute to its success. }\end{array}$ \\
Team & $\begin{array}{l}\text { The whole can be greater than } \\
\text { the sum of its parts }\end{array}$ & $\begin{array}{l}\text { Use your strengths and catalyze the strengths of } \\
\text { others to maximize creativity and impact. }\end{array}$ \\
Self & Leadership begins with self & Dream, learn, do and be daring; bring your best self \\
\end{tabular}




\section{Student Engagement Levels: Balancing Breadth with Depth}

Our program delivery model was designed with three levels of engagement in mind: basic exposure of leadership learning to all undergraduate engineering students; short-term certificates and retreats for a smaller group of students who elect to participate; and high intensity leadership learning opportunities for students who show interest and promise in engineering leadership education. These three levels of engagement allow us to achieve the following program objectives:

- All engineering students will be able to describe the basic elements of leadership.

- Many engineering students will be able to apply leadership skills, tools, and understanding to enhance their effectiveness.

- A few students will embark upon a sustained path of personal leadership growth

As shown in Table 2, basic-level programming provides all students with an appreciation of the nature and value of leadership, mid-level programming offers students opportunities to learn and exercise newfound skills, while highly engaged students may pursue their leadership education at an enhanced level.

\section{Curricular and Co-curricular Program Components}

For the past decade, Leaders of Tomorrow and ILead have provided engineering students at the University of Toronto with intentional, structured, and meaningful leadership development opportunities that help them integrate leadership theory and practice. The institute is distinctive in that it integrates curricular, co-curricular, and extracurricular programming. In addition to the instructional and experiential elements, we use certificates, awards, and scholarships to increase the value placed on leadership, and to promote leadership involvement throughout the Faculty. The sections that follow describe the instructional components included in our current leadership programming.

\section{The curriculum infusion initiative}

In 2008, we launched a curriculum-infusion initiative with two objectives: (1) to provide all engineering students with a basic understanding and awareness of the nature of leadership, and (2) to motivate students to pursue a higher level of engagement through participation in other components of the program. Six "infusion" lectures are presented as one-hour guest-lectures within existing engineering courses. The goal is that every undergraduate student attends

\section{Table 2}

Program components addressing different levels of student engagement

\begin{tabular}{|c|c|c|}
\hline Basic Level & Mid Level & Enhanced Level \\
\hline $\begin{array}{ll}\text { - } & \text { Curriculum infusion } \\
\text { lectures } \\
\text { - } \\
\text { Individual lectures, } \\
\text { seminars or workshops }\end{array}$ & $\begin{array}{ll}\text { - } & \text { Summer programs } \\
\text { - } & \text { Certificate programs } \\
\text { - } & \text { Departmental student } \\
\text { - } & \text { High-intensity retreats }\end{array}$ & $\begin{array}{ll}\text { - } & \text { Courses } \\
\text { - } & \text { Research studies }\end{array}$ \\
\hline
\end{tabular}


all six lectures before graduating. The lecture presentations are combined with personal, in-class learning activities. Thinking frameworks simplifying abstract concepts such as values or vision are a common element. The frameworks are presented as figures since engineering students tend to have a preference for visual learning (Felder \& Brent, 2005). These learning frameworks provide the students with a foundation for thinking about the different aspects of leadership that can be used for structured reflection so as to promote continued leadership learning. The use of assessment inventories and tools allows active personalized learning even in large classrooms. Since 2008, over 100 lectures have been delivered, reaching thousands of students in class sizes ranging from 15 to 700. Anonymous feedback solicited from the students after each lecture indicate that in general the lectures achieve the overall objectives of increasing awareness of the value of leadership and interest in pursuing further leadership development. The growth in our basic level programming to over 8000 attendees per year at leadership lectures and individual events, indicated that we were successfully engaging students and contributing to a greater level of interest in leadership education.

\section{Departmental leadership learning groups}

To create a culture of leadership and a sense of community for students, student leadership groups were formed in all departments and divisions across the Faculty. The intention of the groups is to give students opportunities to practice their leadership. With guidance from appointed faculty and staff members, students generate ideas for events and together turn those ideas into reality. Students build community, engage with alumni, and gain hands-on leadership experience by brainstorming professional development ideas for their peers and implementing them with the support of ILead staff. The range of programming includes panel discussions with industry leaders, personal development workshops, political debates, professional development sessions, and alumni networking. Approximately 100 students participate as core or "executive" working group members each year. The events they organize attract thousands of student attendees each year.

\section{Summer Program}

A fourteen-week summer program on leadership learning for undergraduate engineering students began in 2002 and has attracted more than 400 students to date. Sessions are held on Friday afternoons from May through August. Students who attend $80 \%$ of the workshops receive a non-credit certificate. This program currently has three segments: (1) 'Personal Development' - emphasizing the importance of self-awareness in effective leadership, (2) 'Group Leadership' - the skills that are needed to contribute to and lead teams, and (3) 'Leadership in Society,' promoting the idea of engineers as active citizens and change agents in the world. In addition to seminars, speakers and workshops, students participate in design/research project teams, attend tours of industry facilities, and engage in community service activities (Simpson et al., 2012).

\section{Certificate programs and one-day intensive workshops}

Co-curricular certificate programs are offered during the fall and winter terms in two formats to accommodate students' tightly scheduled timetables: two-hour workshops, over four or five weeks, and one-day "intensive" workshops. We have offered the following programs:

- Learning to Lead: Emerging Leaders - For students interested in getting more involved on campus in a learning community and/or applying for peer mentorship or leadership positions on campus. 
- Team Skills - For students interested in knowing how to build strong teams for group projects and industry experience.

- Leading from the Inside Out - For students who want to discover the power of selfleadership.

- Organizational Leadership - For students who hold or aspire to hold leadership positions in student clubs or organizations.

Students who complete one of these programs receive a printed certificate and a notation in their Co-curricular Record in recognition of their participation. Since the inception of the certificate programs in 2008, there have been 20 offerings and a total enrolment of 731 students. Annual participation has increased continuously from 40 in 2008-09 to 216 in 2013-14.

\section{Leadership in elective courses and in} the core curriculum

The first for-credit course on leadership_-Leadership and Leading for Groups and Organizations-was offered in the fall of 2007 to a mixed class of undergraduate and graduate students. Similar to other ILead initiatives, the introduction and instruction of this course was a collaborative, interdisciplinary endeavour. The principal instructor was a former CEO of Dupont Asia Pacific and then of Dupont Canada, who had ample expertise in engineering and corporate leadership, but had limited experience teaching undergraduate courses to engineering students. After developing and delivering lecture material based on the principles of leadership developed at Dupont Canada over a 20 year period, an ILead staff member with complementary expertise in education facilitated experiential learning exercises to help students engage with and apply the course material. One of many positive outcomes of this course is a recently published textbook merging educational practices with industry-based engineering leadership principles (Colcleugh, 2013).
Several other courses have been developed, each one emerging from our shared vision and values and playing a key role in achieving the overarching goals of the program. These courses are:

- Engineering Leadership

- Cognitive and Psychological Foundations of Effective Leadership

- Positive Psychology for Engineers

- Concepts and Applications of Authentic Leadership

- Engineering Presentations

- The Power of Story: Discovering your Leadership Narrative

The leadership courses are offered at either or both the undergraduate and graduate level and are becoming an integral part of Faculty programming. The graduate courses are part of a special certificate program for the course-based Master of Engineering (MEng) students. The undergraduate courses are approved electives for the Faculty's extremely popular Business Minor and as electives for a Certificate in Engineering Leadership established in 2014. By the end of the 2013-14 academic year, 1115 engineering students at the University of Toronto had enrolled in leadership courses.

\section{Engineering leadership research projects}

As ILead's curricular and co-curricular programmatic offerings began to grow, the Institute's strategic planning team was encouraged by the Dean of Engineering to demonstrate that our initiatives were grounded in evidence. Thus, in 2011, we expanded the ILead mission to include research to support the development of engineering leadership curriculum and pedagogy. Two of these projects are summarized below, the first addressing team skills effectiveness learning and the second investigating how professional engineers conceptualize and enact leadership. 


\section{Project \#1: Team skills effectiveness learning}

ILead's first doctoral student, supervised by the institute's co-directors and a professor from the Faculty of Education, is investigating team skills learning opportunities for undergraduates, especially in large classes, to support the development of an online tool for self- and peer-evaluation of individual effectiveness in a team. This instrument provides engineering students with feedback on their team skills and remedial on-line learning to facilitate improvement of performance. This work is partially funded by The Higher Education Quality Council of Ontario (HEQCO), and more recently, the Social Sciences and Humanities Research Council of Canada (SSHRC). The tool is being used and tested in a core environmental chemistry course, a leadership course, and several large first-year design courses. Recent investigations suggest that this instrument and the associated "team effectiveness framework" enhance leadership learning in technical, design, and elective courses that enroll 100 to 900 students (Sheridan, El Gammal, Phillips, Evans, \& Reeve, 2013; Sheridan, Evans, \& Reeve, 2012, 2014; Sheridan, Reeve, \& Evans, 2012, 2013, 2014).

\section{Project \#2: Theorizing engineering leadership}

In addition to the pedagogically driven research project outlined above, we have undertaken a foundational study to examine how engineers understand leadership; how they lead in the workplace; what skills and behaviours are important to successful engineering leaders, and where engineers learned those skills and behaviors. Our findings, recently published, include a theory of engineering leadership grounded in the day-to-day experiences of professional engineers (Reeve, Sacks, \& Rottmann, 2014; Reeve, Sacks, Rottmann, Daniels, \& Wray, 2013; Rottmann, Sacks, \& Reeve, 2014), and a survey of engineering skills and traits modeled by engineers who have been identified by their peers as exemplary leaders (Reeve, Rottmann, \& Sacks,
2015). While this work is already informing our courses, our ultimate objective is to use our findings to generate professionally relevant, evidenced-based curriculum.

Beyond these two research projects, we have recently received funding to design two evidencebased engineering instructional innovation projects-one on team learning and the other on engineering ethics and equity. Finally, we have returned to our experiential education roots by designing a mixed methods research project to evaluate the impact of undergraduate engineering students' co-curricular experiences on their leadership identity development and leadership learning.

\section{Impact on Student Learning}

While we have not yet conducted a formal program evaluation, we regularly use both qualitative and quantitate measures to assess student learning. For example, we use feedback forms to assess the impact and learning outcomes of our infusion lectures, preand post- surveys to evaluate leadership learning in our co-curricular certificates, institutionally generated course evaluations to assess the efficacy of our instructors, and testimonials-both solicited and unsolicited - to provide us with information about the long-term impact of our programming on alumni. We have used this data to iteratively improve content, program elements, and pedagogy.

Feedback forms following our infusion lectures suggest that, on average, these lectures increase students' interest in learning about leadership, that students see leadership as something you learn after graduation, and that the delivery and content of the lectures is not the main hurdle preventing students from learning about leadership. Qualitative comments on the back of these forms have helped instructors adapt future lectures by learning which components have the greatest impact on student learning. Pre-post surveys which bookend the month-long certificate programs suggest that students perceive themselves as more knowledgeable, self-aware, socially- skilled communicators by the end 
of the course. Institutionally managed course evaluations suggest that students value these learning experiences and recognize the learning as being important to their professional development. Finally, testimonials - including personalized emails, letters written to the Dean and thank you notes from our students and alumni - demonstrate a lasting positive impact on student learning:

The ILead program has been a great
complement to my engineering
education. The program provides an
important opportunity to develop a set
of softer skills that otherwise are not
emphasized in the engineering
curriculum such as teamwork,
communication, awareness of self, and
awareness of others. The skills and
tools taught by ILead have enabled me
to execute and leadprojects much more
effectively than I otherwise would
have. Thanks to the ILead program, I
now feel confident about my ability to
become a strong leader in industry and
society.

Indirectly linked to the growing impact our curricular and co-curricular programing is having on student learning, is our institution's early success in the realms of research and outreach. Our publications, conference presentations, and successful grant applications suggest that audiences of engineering educators, engineering education researchers and leadership researchers are increasingly receptive to our efforts. In terms of outreach, our corporate partnerships enable us to help students make the school to work transition while our status as the only Canadian member of COMPLETE-a working group of engineering schools established in 2010 to support the institutionalization of leadership education in engineering - allows us to maximize our educational impact by learning from and sharing strategies with leadership educators doing similar work in the United States.

\section{Discussion}

As we indicated in the introduction of this paper, the literature on engineering leadership education is still in its infancy. The great majority of articles in this area constitute calls for leadership in engineering education (Downey et al., 2006; Engineers Canada, 2009; Katehi, 2005; Khattak, 2011; Reeve, 2010; Vest, 2005) and under-theorized program descriptions written by insiders (Bayless, 2013; Cox et al., 2010; Croft et al., 2013; Evans et al., 2010; Graham et al., 2009; Ha, 2013; Hsiao, 2013b; Kerns et al., 2005; Khattak, 2011; Osagiede et al., 2013; Pitts et al., 2013; Polito \& Martinich, 2008; Schuhmann, 2010; Simpson et al., 2012). Very few program evaluations have been done on the efficacy of this work and even fewer research studies have been conducted on the conceptual basis of engineering leadership or the implementation of engineering leadership education across institutional, provincial, or national contexts.

One notable exception is Ruth Graham's evaluation of engineering leadership (Graham, 2012a, 2012b; Graham et al., 2009). Graham's central finding was that leadership education in engineering faculties was prevalent, but insufficiently systemic_-piecemeal, isolated innovations lacking resources and institutional support. Most reforms quickly reverted back to the "status quo" after seed funding expired. Relevant to the Canadian context, Graham and her colleagues also found a distinction between US-based programs and programs located in other countries. The American programs were more explicitly focused on leadership, had been established more recently, and tended to be better resourced while those located elsewhere had an implicit focus on leadership, had longer institutional histories, and were typically less well resourced. Only two engineering leadership programs were identified in Canada_ILead/Leaders of Tomorrow, and a graduate program blending engineering with public policy and design at McMaster University. Graham's evaluation of educational reform in engineering leadership education provides us with useful feedback about how to proceed, but it also misses the nuanced 
and contextualized details present in institutional case studies.

Our paper presents one such case study, told by organizational insiders committed to improving leadership learning and student experience in engineering education. Graham's snapshot of our program in 2009 cast doubt on our potential sustainability, but as a learning organization (Senge, 1990) informed by leadership identity development theory (Komives et al., 1998) and experiential education (Kolb, 1984), we have learned from and have begun to implement her recommendations. In particular, we have reflected on her findings that successful initiatives can be sustained through crossfaculty delivery of reformed courses, well-designed impact evaluations and ongoing focus on innovation (Graham, 2012a, 2012b; Graham et al., 2009). Finally, feedback from University of Toronto engineering students, colleagues, and senior administrators help shape our needs-based program into a vehicle for leadership identity development and professional growth for engineering students seeking to complement their technically oriented education. This paper, along with our program is a work in progress.

\section{Significance, Limitations, and Next Steps}

Engineers are well positioned to create innovative solutions to many local and global challenges, yet few Canadian faculties of engineering prepare them to do this work. One way to improve engineers' capacity to bring about socially meaningful change is to provide them with intentional leadership learning opportunities and the intrapersonal, interpersonal, team, and organizational skills necessary to translate technical capabilities into work that benefits society. In this paper, we have presented the 12 year evolution of one such program - the Institute for Leadership Education in Engineering (ILead) - from its infancy in 2002 to its current state as a multi-faceted, multidisciplinary program.
The primary significance of this work is programmatic rather than theoretical in nature. We have introduced leadership learning to undergraduate engineering students through large-scale infusion lectures, provided scaffolding to student leaders interested in shaping and delivering professional development opportunities to their peers, and challenged students in our courses and certificate programs to supplement their technical competencies with social, self and organizational awareness. In the end, our greatest strength has stemmed from our programmatic diversity. The faculty and staff who envisioned and implemented leadership programming for engineering students at the University of Toronto have used their distinct disciplinary backgrounds, values and motivations to build a program from the ground up in response to a wide range of student needs. After twelve years, our innovative start-up-Leaders of Tomorrow-has grown into a Faculty of Engineering institutionThe Institute for Leadership Education in Engineering. Similar to other start-ups, the creative energy driving our initial growth has changed the educational landscape for our students, thereby necessitating a new strategic response. As Larry Greiner theorized in his classic article on growing organizations, periods of evolutionary growth tend to be followed by periods of revolutionary crisis (Greiner, 1972). If and when each crisis is resolved, the organization moves through another period of growth, which in turn leads to another crisis. This process continues as organizations grow and mature.

At ILead, we have grown through many challenges, in each case progressing and maturing into a more durable organization. Perhaps our greatest struggle to date has followed from our programmatic goals to meet expectations embedded in temporary funding opportunities. This has led to somewhat piecemeal offerings. This external limiting factorcommon to many organizations - has inhibited our willingness to take stock of our program as a whole. Fortunately, however, we have recently engaged in a successful program review process that may lead to increased sustainability. In response to this excellent opportunity, it is incumbent upon us to look internally and ask ourselves some difficult questions. 
What is ILead's central contribution to the Faculty of engineering? How can we sustain our programming in a way that balances student needs, institutional structures, and available resources? How can we infuse engineering-specific competencies into our personal development-based leadership program? How can we engage students and faculty members who resist the idea that engineering is a leadership profession? How can we more tightly connect our emerging research program with our curricular and co-curricular practices? What kind of impact does our program have on alumni success in the workplace? What are we doing well and in what ways are we falling behind?

As our program grows and matures, we must challenge ourselves to respond to these questions and reach out to new audiences. The iterative learning that has informed our process to date will enable us to address each of these issues as we balance programmatic diversity with programmatic coherence. If we do so while continuing to draw on the expertise and passions of the co-directors, teaching staff, research staff, administrative staff, and students we will not only help our students lead change to build a better world, but also change ourselves in ways that demonstrate organizational learning, leadership development, and experientially informed growth.

\section{References}

Athreya, K. S., Bhandari, N., Kalkhoff, M. T., Rover, D. T., Black, A. M., Miskioglu, E. E., \& Mickelson, S. K. (2010, October). Work in progress-Engineering Leadership Program: A thematic learning community. Paper presented at the ASEE/IEEE Frontiers in Education Conference, Washington, DC. http://dx.doi.org/10.1109/FIE.2010.56731 13

Bayless, D. J. (2013, June). Developing leadership skills in engineering students: Foundational approach through enhancement of self- awareness and interpersonal communication. Paper presented at the Canadian Engineering Education Association Conference, Montreal, QC. Retrieved from http://library.queensu.ca/ojs/index.php/PC EEA/index

Colcleugh, D. (2013). Everyone a leader: A guide to leading high-performance organizations for engineers and scientists. Toronto: University of Toronto Press.

Colcleugh, D., \& Reeve, D. W. (2013, June). Translating a corporate leadership philosophy and practice to the engineering classroom. Paper presented at the Canadian Engineering Education Association Conference, Montreal, QC. Retrieved from http://library .queensu.ca/ojs/index.php/PCEEA

Cox, M. F., Osman, C., \& Adams, S. G. (2010). Developing leadership skills of undergraduate engineering students: Perspectives from engineering faculty. Journal of STEM Education: Innovations \& Research, 11(3/4), 22-33.

Croft, E. A, Winkelman, P., Boisvert, A., \& Patten, K. (2013, June). Global engineering leadership: Design and implementation of local and international service learning curriculum for senior engineering students. Paper presented at the Canadian Engineering Education Association Conference, Montreal, QC. Retrieved from http:// library.queensu.ca/ojs/index.php/PCEEA

Downey, G. L., Ludena, J. C., Moskal, B. M., Parkhurst, R., Bigley, T., Hays, C., . . . Nichols-Belo, Amy. (2006). The globally competent engineer: Working effectively with people who define problems differently. Journal of Engineering Education, 95, 107122. http://dx.doi.org/10.1002/j.21689830.2006.tb00883.x 
Engineers Canada. (2009). Leading a Canadian future: The new engineer in society. Montreal, QC: Canadian Engineering Leadership Forum, Engineers Canada. Retrieved from http://www.acec.ca/assets/pdf/events/Summ it_Declaration_English_Final.pdf

Ellis, L. A, \& Petersen, A. K. (2011). A way forward: Assessing the demonstrated leadership of graduate civil engineering and construction management students. Leadership and Management in Engineering, 11, 88-96. http://dx.doi.org/10.1061/(ASCE)LM.1943 $-5630.0000107$

Evans, G. J., Reeve, D. W., \& Simpson, A. E. (2010, June). Introducing leadership learning in engineering classrooms. Paper presented at the Canadian Engineering Education Association Conference, Kingston, ON. Retrieved from http://library.queensu.ca /ojs/index.php/PCEEA

Felder, R. M., \& Brent, R. (2005). Understanding student differences. Journal of Engineering Education, 94, 57-72. http://dx.doi.org/ 10.1002/j.2168-9830.2005.tb00829.x

Graham, R. (2012a). Achieving excellence in engineering education: The ingredients of successful change (pp. 74). London: The Royal Academy of Engineering \& Massachusetts Institute of Technology. Retrieved from http://www.raeng.org.uk/ publications/reports/achieving-excellencein-engineering-education

Graham, R. (2012b). The one less traveled by: The road to lasting systemic change in engineering education. Journal of Engineering Education, 101, 596-600. http://dx.doi.org/ 10.1002/j.2168-9830.2012.tb01120.x

Graham, R., Crawley, E., \& Mendelsohn, B. R. (2009). Engineering leadership education: $A$ snapshot review of international good practice [White paper]. Retrieved from R H Graham Consulting Limited website: http://www. rhgraham.org/RHG/Recent_publicatons_fil es/ELE\%20White\%20Paper-102109.pdf

Greiner, L. E. (1972). Evolution and revolution as organizations grow. Harvard Business Review, 50(4), 37-46. https://hbr.org/1998/05/ evolution-and-revolution-as-organizationsgrow/ar/1

Ha, M. R. (2013, June). Experiential learning in leadership development: Select program at McMaster University. Paper presented at the Canadian Engineering Education Association Conference, Montreal, QC. Retrieved from http://library.queensu.ca/ojs/ index.php/PCEEA/article/view/4831

Hsiao, A. (2013a, June). Developing an entrepreneurial mindset in engineeirng students. Paper presented at the Canadian Engineering Education Association Conference, Montreal, QC. Retrieved from http://library.queensu.ca/ojs/index.php/PC EEA

Hsiao, A. (2013b, June). Developing engineering managers: The master of engineering management program at Memorial University of Newfoundland. Paper presented at the Canadian Engineering Education Association Conference, Montreal, QC. Retrieved from http://library.queensu.ca/ojs /index.php/PCEEA

Katehi, L. (2005). Educating the engineer of 2020: Adapting engineering education to the new century. IEEE Engineering Management Review, 37(1), 11-16. http://dx.doi.org/10. 1109/EMR.2009.4804343

Kerns, S. E. Miller, R. K, \& Kerns, D. V. (2005). Designing from a blank slate: The 
development of the initial Olin College curriculum. In NAE (Ed.)., Educating the engineer of 2020: Adapting engineering education to the new century (pp. 98-113). Washington, DC: National Academies Press.

Khattak, H. N. (2011, February). Engineering leadership education: Rationale and challenges for the future. Paper presented at the IEEE GCC Conference and Exhibition, Dubai, United Arab Emirates. http://dx.doi.org/ 10.1109/IEEEGCC.2011.5752561

Kolb, D. A. (1981). Learning styles and disciplinary differences. In A. W. Chickering (Ed.), The modern American college: Responding to the new realities of diverse students and a changing society (pp. 232-255). San Francisco: JosseyBass.

Kolb, D. A. (1984). Experiential learning: Experiences as the source of learning and development. Englewood Cliffs, NJ: Prentice-Hall.

Komives, S. R., Lucas, N., \& McMahon, T. R. (1998). Exploring leadership: For college students who want to make a difference. San Francisco: Jossey-Bass.

Kouzes, J. M., \& Posner, B. Z. (1987). The leadership challenge: How to get extraordinary things done in organizations. San Francisco: Jossey-Bass.

McCuen, R. H. (1999). A course on engineering leadership. Journal of Professional Issues in Engineering Education and Practice, 125, 7982. http://dx.doi.org/10.1061/(ASCE) 1052 $-3928(1999) 125: 3(79)$

McMartin, D. W. (2013, June). Service learning and team work: Elements of leadership. Paper presented at the Canadian Engineering Education Association Conference, Montreal, QC. Retrieved from http://library.queensu.ca/ojs/index.php/PC EEA
National Academy of Engineering. (2004). The engineer of 2020: Visions of engineering in the new century. Washington, DC: National Academies Press.

Osagiede, A., Farmer Cox, M., \& Ahn, B. (2013, June). Purdue University's Engineering Leadership Program: Addressing the shortfall of engineering leadership education. Paper presented at the 120th ASEE Annual Conference and Exposition, Atlanta, GA. Retrieved from http://www.asee.org/public/ conferences/20/papers/7314/view

Pitts, S., Klosterman, S., \& McGonagle, S. (2013, June). A successful approach to educating engineering leaders at the graduate level. Paper presented at the Canadian Engineering Education Association Conference, Montreal, QC. Retrieved from http:// library.queensu.ca/ojs/index.php/PCEEA/ar ticle/view/4819

Polito, C., \& Martinich, L. (2008, June). Leadership: So easy even an engineer can do it! Paper presented at the IEEE International Engineering Management Conference, Estoril, Portugal. http://dx.doi.org/10.1109/ IEMCE.2008.4618020

Reeve, D. W. (2010). There is an urgent need for engineering leadership education. Engineering Leadership Review, 1(1), 1-6. http://jps.library.utoronto.ca/index.php/elr/ article/view/10671/9205

Reeve, D. W, Rottmann, C., \& Sacks, R. (2015, June). The ebb and flow of engineering leadership orientations. Paper presented at the American Society of Engineering Education Annual Conference and Exposition, Seattle, WA.

Reeve, D. W, Sacks, R., \& Rottmann, C. (2014, June). A responsibility to promote leadership: 
Engineering entrepreneurs speak back to resistance. Paper presented at the Canadian Engineering Education Association Conference, Calgary, AB.

Reeve, D. W., Sacks, R., Rottmann, C., Daniels, F., \& Wray, A. (2013, June). Engineer leadership in organizations and the implications for curriculum development. Paper presented at the Canadian Engineering Education Association Conference, Montreal, QC. Retrieved from http://library.queensu.ca/ojs /index.php/PCEEA/issue/view/477

Reeve, D. W, Simpson, A. E., \& Evans, G. J. (2010, June). The leader-engineer: Capabilities, competencies and attributes. Paper presented at the Canadian Engineering Education Association Conference, Kingston, ON. Retrieved from http://library.queensu.ca/ ojs/index.php/PCEEA/issue/view/338

Rottmann, C., Sacks, R., \& Reeve, D. W. (2014). Engineering leadership: Grounding leadership theory in engineers' professional identities. Leadership. Advance online publication. http://dx.doi.org/10.1177/ 1742715014543581

Scharmer, C. O. (2008). Uncovering the blind spot of leadership. Leader to Leader, 2008(47), 5259. http://dx.doi.org/10.1002/ltl.269

Schuhmann, R. J. (2010). Engineering leadership education - The search for definition and a curricular approach. Journal of STEM education: Innovations and Research, 11(3/4), 61-69.

Senge, P. M. (1990). The fifth discipline: The art and practice of the learning organization. New York: Doubleday.

Sheridan, P. K, El Gammal, L., Phillips, J., Evans, G. J., \& Reeve, D. W. (2013, June). A teameffectiveness inventory for guided reflection and feedback. Paper presented at the American Sciety for Engineeering Education Conference and Exposition, Atlanta, GA.

Sheridan, P. K, Evans, G. J, \& Reeve, D. W. (2012, June). A proposed framework for teaching team-effectiveness in team-based projects. Paper presented at the American Society for Engineering Education Conference and Exposition, San Antonio, TX.

Sheridan, P. K, Evans, G. J, \& Reeve, D. W. (2014, June). Understanding teaching assistants' assessment of individual teamwork performance. Paper presented at the American Society of Engineering Education Annual Conference and Exposition, Indianapolis, IN.

Sheridan, P. K., Reeve, D. W., \& Evans, G. J. (2012, June). Self- and peer-assessments of teameffectiveness in a first year engineering design course. Paper presented at the Canadian Engineering Education Association Conference, Winnipeg, MB. Retrieved from http://library.queensu.ca/ojs/index.php/PC $\mathrm{EEA} /$ issue/view/399

Sheridan, P. K., Reeve, D. W., \& Evans, G. J. (2013, June). Student perceptions and use of an inventory to facilitate learning of individual team-effectiveness. Paper presented at the Canadian Engineering Education Association Conference, Montreal, QC. Retrieved from http://library.queensu.ca/ojs/ index.php/PCEEA

Sheridan, P. K, Reeve, D. W, \& Evans, G. J. (2014, June). An on-line team-effectiveness learning system. Paper presented at the Canadian Engineering Education Association Conference, Canmore, AB.

Simpson, A. E., Evans, G. J., \& Reeve, D. W. (2010, June). A summer leadership development 
program for chemical engineering students. Paper presented at the Canadian Engineering Education Association Conference, Kingston, ON. Retrieved from http://library.queensu.ca/ojs/index.php/PC $\mathrm{EEA} /$ issue/view/338

Simpson, A. E., Evans, Greg J., \& Reeve, D. W. (2012). A summer leadership development program for chemical engineering students. Journal of Leadership Education, 11(1), 222232. http://library.queensu.ca/ojs/index.php /PCEEA

Soundarajan, N., Ramnath, R., \& Weide, B. W. (2013, June). A multi-pronged approach to nurturing IT entrepreneurs. Paper presented at the 120th ASEE Annual Conference and Exposition, Atlanta, GA. Retrieved from http://www.asee.org/public/conferences/20/ papers/7931/view

Vest, C. M. (2005). Educating engineers for 2020 and beyond. In NAE (Ed.), Educating the engineer of 2020: Adapting engineering education to the new century (pp. 160-170). Washington, DC: National Academies Press.

\section{Acknowledgements}

The ILead team would like to acknowledge our funders, most notably Bill and Kathleen Troost. We also deeply appreciate the support of Cristina Amon, Dean of the Faculty of Applied Science and Engineering at the University of Toronto. We would also like to thank the companies that have partnered with us in our research, Google Canada, Hatch, Vale and ERCO Worldwide. We also extend our thanks to members of the broader ILead team (David Colcleugh, Alison McGuigan, Nick Evans, Wayne Stark, Kristina Minnella, Brian Tran, Amy Huynh, Deborah Peart and Cecilia Konney) and of course to our remarkable students who inspire our work.
The Alan Blizzard Award was established to encourage, identify, and publicly recognize those whose exemplary collaboration in university teaching enhances student learning. The Award honours Dr. Alan Blizzard, STLHE President from 1987 to 1995 , and his convictions about the effectiveness of collaboration in team teaching for student learning. The Award seeks to make visible and disseminate scholarship of teaching and learning, based on values and practices of collaborative teaching.

\section{Biographies}

Doug Reeve, Director, is the founding Director of the Institute for Leadership Education in Engineering (ILead) at the University of Toronto. For over twenty-five years, he has worked to provide leadership learning opportunities to engineering students. In addition to his service in academia, Prof. Reeve has worked with industry as a consultant and president of a small consulting firm for fourteen years, frequently on international assignments. He has created and led professional development short courses on over 50 occasions reaching over 5000 attendees. Numerous awards have recognized his contributions to the profession and to research. He is Professor in the University of Toronto's Department of Chemical Engineering \& Applied Chemistry and served as Department Chair from 2001-2011.

Greg Evans, Associate Director, is a Professor of Chemical Engineering \& Applied Chemistry and a former Vice-Dean Undergraduate and Chair First Year in the Faculty of Applied Science \& Engineering at the University of Toronto. He is also the founding Director of the Southern Ontario Centre for Atmospheric Aerosol Research (SOCAAR), an interdisciplinary research centre studying the environmental and health impacts of air pollutants. Prof. Evans's interest in creating a structured leadership development program for engineering students grew from his desire to see engineers take a more proactive role in the many technologically related issues that face society. 
Annie Simpson, Assistant Director, has a Master degree in Adult Education and Counselling Psychology and has completed the course work portion of a $\mathrm{PhD}$ in Education. She has been with ILead since it became a Faculty-wide initiative in 2007 and has overseen the co-curricular elements of the program. Annie has taught in the community college system and has also worked as a counselor, conflict mediator, and restorative justice facilitator and trainer. Annie is committed to transformative education that engages the whole person. She is inspired to offer engineering students opportunities to cultivate their leadership through self-discovery, team experiences, and community engagement.

Robin Sacks, Director of Research, joined ILead to develop curricular and co-curricular leadership education for the Faculty and now serves as its Director of Research. She received a Master degree in Applied Cognitive Science and a Ph.D. in Human Development and Applied Psychology from U of T's Ontario Institute for Studies in Education. Robin's interest in leadership education grew from her own experiences as a young student leader on campus. She is the founder of Peace by PEACE Canada-a student-run not-for-profit organization that teaches conflict resolution, self-esteem, and community building skills to primary school students.

Estelle Oliva-Fisher, Leadership Education Specialist, brings tremendous Student Life experience to ILead. She has worked as a Residence Life Coordinator at the University of Toronto Mississauga, a Student Life Coordinator for the Office of Student Life, and most recently was the Assistant Director, Student Life and Leadership at New College. Her career has been committed to helping students engage in campus life and leadership opportunities. Estelle recently finished her Master of Education at OISE-UT in the Adult Education and Community Development Graduate
Program. Estelle has particular interest in workplace learning and social change, as well as transformative leadership education.

Cindy Rottmann, Research Associate, joined ILead on the Engineering Leadership Project in October 2012. She has an M.A. and Ph.D. in Theory and Policy Studies in Education, with a focus on Educational Administration. Cindy brings extensive research, teaching, and curriculum development experience to the team. She has worked on eight federally funded studies resulting in 22 publications and 32 conference presentations. She has taught mathematics \& science to secondary school students, and educational leadership \& policy to school administrators. Prior to joining ILead she was an Assistant Professor of Educational Administration at the University of Manitoba. Cindy's research interests include engineering leadership, engineering ethics and equity, teacher leadership, and social justice teacher unionism.

Patricia Sheridan, PhD Candidate, received her B.A.Sc. (2009) and M.A.Sc. (2011) in Mechanical Engineering from the University of Toronto. Throughout her studies Patricia pursued numerous leadership roles, initiating the UTFIRST Robotics Mentorship program, and coordinating the University of Toronto Engineering Kompetitions. Having taught and engaged in research in engineering design education during her Master program, Patricia decided to turn her interest in developing engaging engineering curricula into a career. She is now pursuing doctoral studies at the Institute for Leadership Education in Engineering under the supervision of Profs. Evans and Reeve. Her research involves developing web-based applications to teach team-effectiveness through team-based projects and integrating team-effectiveness education into the engineering curricula. 